\title{
Analysis of Coherence and Cohesion on Students' $\square=$ Academic Writing: A Case Study at the 3rd year Students at The English Education Program
}

Page $\mid 74$

Alsuna: Journal of Arabic and English Language

Leli Lismay

Institut Agama Islam Negeri Bukittinggi

syarliatsiilah@gmail.com

\section{Keywords:}

Coherence

Cohesion

Comprehension

Academic Writing

\section{Article Information:}

Submitted: 22 September, 2020

Accepted: 04 Nopember, 2020

Approved: 11 Nopember, 2020

\section{Abstract}

Purpose - This research aims to analyze the understanding of coherence and cohesion made by the 3rd year students of English education program on their academic writing at Islamic Institute of Bukittinggi.

Design/methodology/approach - This was descriptive research which explains the phenomena concerns on the data due to field finding. This research applied for the library based work where the data was taken by using document analysis and interview.

Findings - The result of the research showed that the numbers of students were still difficult to construct the idea cohesively and coherently. The result of the students' understanding on coherence and cohesion showed that there were 59\% students who were considered in need to improve and also followed by good work and could be better with $27 \%$ and $14 \%$ respectively. It can be explained that students were lack of ability to write the idea smoothly and grammatically correct. The interview result showed that there were three main reasons for this. Those are lack of motivation, limited lecture duration and prior English knowledge.

Originality/value - coherence and cohesion are parts of academic writing that should be mastered by students in order to create a good thesis. Specifically for the students who will graduate from Higher Education.

Paper type - Research paper

\section{Introduction}

Academic writing, in a wide issue, is a scientific assignment to accomplish a particular obligation, such as writing books, research paper, dissertation and thesis. It is obvious that all of the university students are required to able to writing academically. The reason occurs because university students will face the upcoming challenge, which is doing a thesis. Regarding to Irvin in (Poudel 2018) that scientific writing is always a form of assessment that requires a demonstration of knowledge and illustrate proficiency, being particular disciplinary 
skill on though, interpreting and presenting. In writing, the position of grammar and syntax are crucial in order to allow the learners to make an intelligible sentence (Aziz 2020). The various method has been used to teach language as a foreign language in Indonesia, such as contextual teaching and learning (Aziz and Dewi 2019). Writing requires a high level of learning concern the ability of mastering grammar, vocabulary, coherence etc (Sholah 2019). Due to the expert, it clearly defines academic writing always describing your prior knowledge both thinking and presenting an idea. Students supposed to learn how to explore the better argument in order to illustrate in writing script.

As English education study program students, require to write the script utilizing English due to the conditions set by the faculty so that students are expected to have the capability in expressing an idea through English. (Lismay and Zubaidah 2019) state that in expressing the idea, students need to find better strategies that suit their style in learning. However, writing is not simply a matter of revealing critical arguments. Students need to consider cohesion and coherence as the important devices in the writing quality. Many of the students in Higher Education still find difficulties in making their writing coherent due to their limitation in understanding the cohesive devices and their application in their writing (Suwandi 2016). (Crossley et al. 2010) strengthened that there is a strongly held sense that essay quality is highly related to the cohesion and coherence of the essay. It means that students' writing quality will be admitted by having a great understanding of implementing cohesion and coherence into. Without both parts, students cannot interest the readers due to the unstructured writing. In fact, producing cohesive and coherence in a piece of academic writing is an enormous challenge, especially in EFL students. (N.A.W 2016) stated that "a text or a paragraph which uses cohesion and coherence must be a good writer." Writing is more complicated as the students need to unite the idea well, pattern and English competence. (N.A.W 2016) also strengthens that cohesion and coherence mean that all of the parts of the sentences are connected logically and linguistically to form a whole. Therefore, both cohesion and coherence must be considered by the students while expressing ideas in writing in order to have valuable paragraphs.

Looking more closely at cohesion, the interest of this type of research has been starting in the past many years. It happens because this part of writing is necessary in order to combine the sentences such as using a conjunction. (Tangkiengsiriin 2010) states that according to whom cohesion is "the means available in the surface forms of the text to signal relations that 
hold between sentences or clausal units in the text" The study shows the beneficiary among one clause to other clauses by giving a linking or conjunction, in relation to the sentence connection.

Besides cohesion, there is also another part which is necessary to smoothing the sentences. It is called coherence. Coherence cannot be separated in writing because it is needed to create writing logically. (Mark Briesmaster 2017) stated that coherence makes every sentence flows smoothly and logically. The study illustrates that coherence requires students to be good at arranging ideas. How the idea in a paragraph connects to further paragraph.

As cohesion and coherence are required in academic writing, lecturers need to guide the students to have capacity on writing. According to Ahmed "As many teachers of English have noted, acquiring writing skill seems to be more laborious and demanding than acquiring the other language skills (Ahmed 2010). It is obvious that lecturers are the facilitator to the students in order to help them to construct the structured ideas because lectures are aware it is challenges skills to master. Furthermore, analyzing coherence and cohesion is crucial due to the requirement in finishing the study of Higher Education in Indonesia is conducting research on Academic English.

\section{State of The Arts and Distinguish}

Crossley et.al state that cohesion directly gives an effect to the text comprehension, while coherence is an important part of the quality of an essay (Crossley et al. 2010). Furthermore, the role of coherence and cohesion can evaluate the quality of the essay. Ahmed explains that the teaching materials used should cover a wide range of skill on how to master cohesion and coherence related to a different level of proficiency the students had so that feedback should be given information of oral and written feedback (Ahmed 2010). Moreover, Ashani et.al mention limited time in the classroom teaching activities lead to the poor capacity of understandable writing and some operational solution were given to improve students' ability to write coherent and cohesive text (Ashani Michel Dossoumou, Mahugnon everin mehouenou 2018).

Related to the mentioned background, the research problem on this research was "what were the students' understanding of coherence and cohesion in their Academic Writing?". The objective of the research is to analyze the comprehension of coherence and 
cohesion on students' academic writing at the 3rd year of English education program of Islamic Institute of Bukittinggi. This research was conducted in order to know the students' understanding in writing academic text coherently and cohesively.

Page $\mid 77$

\section{Methodology}

This study used descriptive qualitative research. Based on (M.E 2013) that Descriptive research is purposed to describe the phenomena. Phenomena description is treated systematically which concerns on the data due to the field finding. Walliman also states that Qualitative data cannot be accurately measured and counted, and are generally expressed in words rather than numbers (Nicholas 2011). Both experts have clearly defined that descriptive qualitative research involves the researcher to express an argument related to the findings got from the field. It means that this study is not needed to present numeric to show the findings.

To collect the data, the researcher used document analysis and interview in order to gain a specific study.

\section{Document analysis}

In this research, the researcher decides to take a mid-semester test from twenty-nine students in PBI-A as the documentation for the instrumentation. According to Sugiyono, documentation is the record of events that had passed, and it can be written picture or monumental works from someone (Sugiyono 2016). In other sides, Arikunto also mentioned that documentation is written item (Arikunto 1999). With regards to the experts, this type of research instrument needs a document that is used to identify the content (Creswell 2012). The researcher aims to know how many students are good at cohesion and coherence ability in academic writing, which is a required course before taking the thesis.

\section{Interview}

Document analysis is not the only instrumentation that was used in this research. The researcher also used an open interview to gain specific reason regarding the problems why students were still difficult to construct idea cohesively and coherently. There were ten items asked as an interview guideline. According to Gay, an interview is a purposeful interaction in which one person obtains information from another (Gay 2000). The researcher considered the students who are not good at cohesion, and coherence became the informant to present the reasons why the students did not comprehend cohesion and coherence yet. There were 
ten students out of twenty-nine students who became the informant which were the sixth semester.

\section{Findings and Discussion}

The researcher collected the data from students' academic writing mid semester test from $\mathrm{PBI}$ A class of English education study program at IAIN Bukittinggi. There were approximately twenty-nine students who submitted the projects. From the tasks, the lecturer asked the students to make a thesis proposal from Academic writing subject in order to prepare students' capacity before taking a thesis course. It was necessary because students needed to be prepared before taking the course as the compulsory in IAIN Bukittinggi. To make the analysis process easily, formerly the researcher decided to use rubric assessment which was adapted from (Poudel 2018). The rubric provided 4-assessment levels with 4criteria to count the writing ability.

The researcher considered to use the rubric is to simplify the document analysis process as it became the guidance to the researcher in order to investigate students' writing quality. The rubric assessment could be looked at the following figure:

\begin{tabular}{|c|c|c|c|c|}
\hline \multirow[t]{2}{*}{ Criteria } & \multicolumn{4}{|c|}{ Level of Writing ability } \\
\hline & Outstanding & Good work & Could do better & Need to improve \\
\hline $\begin{array}{l}\text { Main } \\
\text { Idea/Topic } \\
\text { Sentence }\end{array}$ & $\begin{array}{l}\text { 1. Main idea or topic } \\
\text { sentence stated clearly } \\
\text { and accurately. } \\
\text { 2. There is only one main } \\
\text { idea or topic sentence in } \\
\text { the right place (either in } \\
\text { the first paragraph or the } \\
\text { last paragraph). }\end{array}$ & $\begin{array}{l}\text { 1. Main idea or topic } \\
\text { sentence stated } \\
\text { fairly clearly and } \\
\text { accurately. } \\
\text { 2. There is only one } \\
\text { main idea or topic } \\
\text { sentence, but they } \\
\text { are not in the right } \\
\text { place (neither in the } \\
\text { first paragraph nor } \\
\text { the last paragraph). }\end{array}$ & $\begin{array}{l}\text { 1. Main idea or topic } \\
\text { sentence somewhat } \\
\text { stated, unclear and } \\
\text { inaccurate. } \\
\text { 2. There is more } \\
\text { than one main idea } \\
\text { or topic sentence, } \\
\text { and they are not in } \\
\text { the right place } \\
\text { (neither in the first } \\
\text { paragraph nor the } \\
\text { last paragraph). }\end{array}$ & $\begin{array}{l}\text { 1. Main idea or } \\
\text { topic sentence } \\
\text { stated not at all } \\
\text { clear or accurate. } \\
\text { 2. Main idea or } \\
\text { topic sentence } \\
\text { shows complete } \\
\text { confusion }\end{array}$ \\
\hline $\begin{array}{l}\text { Supporting } \\
\text { Details }\end{array}$ & $\begin{array}{l}\text { The main idea is } \\
\text { supported by six or more } \\
\text { sentences that give } \\
\text { details about it. }\end{array}$ & $\begin{array}{l}\text { The main idea is } \\
\text { supported by four or } \\
\text { five sentences that } \\
\text { give details about it. }\end{array}$ & $\begin{array}{l}\text { The main idea is } \\
\text { supported only by } \\
\text { one to three } \\
\text { sentences that give } \\
\text { details about it. }\end{array}$ & $\begin{array}{l}\text { There are no } \\
\text { obvious } \\
\text { supporting detail } \\
\text { sentences to back } \\
\text { up the main idea. }\end{array}$ \\
\hline
\end{tabular}




\begin{tabular}{|c|c|c|c|c|}
\hline $\begin{array}{l}\text { Transition } \\
\text { Signals in } \\
\text { Use }\end{array}$ & $\begin{array}{l}\text { Transition signals } \\
\text { (sentence connectors, } \\
\text { clause connectors, and } \\
\text { others) properly in every } \\
\text { paragraph and manages } \\
\text { them well. }\end{array}$ & $\begin{array}{l}\text { Writing uses a range } \\
\text { of transition signals } \\
\text { appropriately, } \\
\text { although there may } \\
\text { be some under- } \\
\text { lover-use in some } \\
\text { paragraphs. }\end{array}$ & $\begin{array}{l}\text { Writing uses } \\
\text { transition signals, } \\
\text { but in some } \\
\text { paragraphs, there } \\
\text { may be faulty or } \\
\text { mechanical. }\end{array}$ & $\begin{array}{l}\text { Writing uses } \\
\text { transition signals } \\
\text { inadequate, } \\
\text { inaccurate or over } \\
\text { in every } \\
\text { paragraph. }\end{array}$ \\
\hline $\begin{array}{l}\text { Spelling \& } \\
\text { Punctuation }\end{array}$ & $\begin{array}{l}\text { All sentences use correct } \\
\text { spelling, capital and } \\
\text { punctuation. }\end{array}$ & $\begin{array}{l}\text { Sentences have a } \\
\text { few errors in } \\
\text { spelling, capital and } \\
\text { punctuation. }\end{array}$ & $\begin{array}{l}\text { Sentences have fair } \\
\text { number error of } \\
\text { spelling, capital and } \\
\text { punctuation. }\end{array}$ & $\begin{array}{l}\text { Sentences have } \\
\text { no control over } \\
\text { spelling, capital } \\
\text { and punctuation. }\end{array}$ \\
\hline
\end{tabular}

Table 1: Assessment rubric for academic writing

The result showed that the numbers of students were still difficult to construct the idea cohesively and coherently. It was proven by the data through pie chart below.

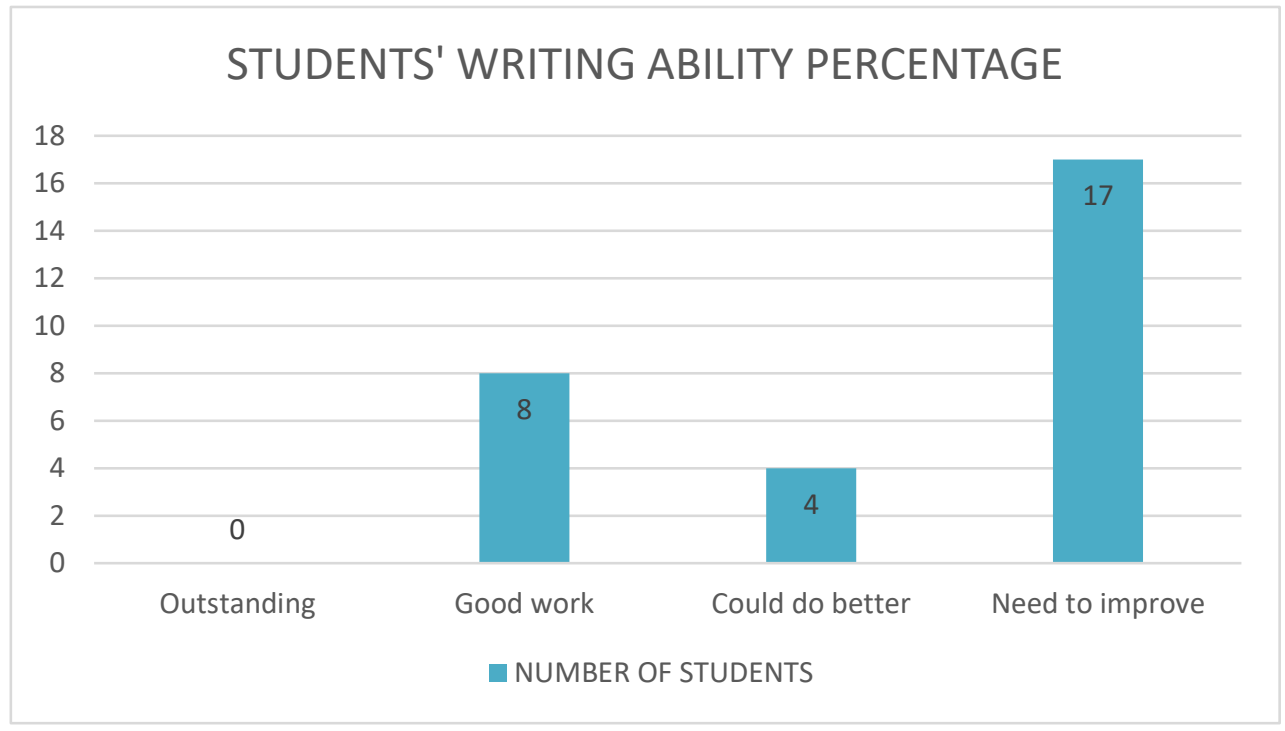

Figure 1: Students' understanding of coherence and cohesion

The pie chart illustrated that there were $59 \%$ of students who were considered in need to improve and also followed by good work and could do better with $27 \%$ and $14 \%$ respectively. However, there were not students who obtain outstanding category as academic writing is not as easy as remaining English skills. The standard was captured based on the assessment rubric for academic writing in table 1.

The researcher found that the students were still lack of ability to write the idea grammatically and smoothly. It was proven by the ability to combine clause which was still 
low. Moreover, students mostly express the idea unsystematically; for instance, a paragraph to the next paragraph never made sense.

Furthermore, to strengthen the data, the researcher also held the interview to ten students from twenty-nine students as the sample in order to obtain the specific data from the informant so that researcher knew why the students were still lack of ability in academic writing with cohesion and coherent capability. Based on the interview, the researcher obtained the finding that there are three main reasons appeared by the students. Those are lack of motivation, limited lecture duration and prior English knowledge.

From ten informants, there are ten students who answered motivation and limited lecture duration influenced the writing performance. However, only seven students who stated the prior English knowledge impacted on your writing capacity. According to the interview, most of the students were aware that academic writing is necessary, even there were many obstacles faced by the students.

Therefore, students' writing ability, especially in cohesion and coherent, was impacted by particular problems.

\section{Conclusion}

Academic writing becomes a compulsory subject in English education study program at IAIN Bukittinggi. It occurs because the subject is a preparatory tool to face the thesis as the requirement to obtain the degree. In writing, cohesion and coherent always exists because both can smoothen the arrangement so that reader will be easy to understand the idea. The students' understanding of coherence and cohesion on the 3rd year of English Department at IAIN Bukittinggi needs to be improved. While 59\% of students did not understand how to to write academic writing coherently and cohesively, only $27 \%$ of students did a good work on understanding coherence and cohesion. However, most of the students are difficult to construct the idea of cohesively and coherently. It is due to particular reasons, such as lack of motivation, limited lecture duration and prior English knowledge. Those reasons bother students' capacity in academic writing so that the students express ideas through the writing usuriously. In result, cohesion and coherent ability decreased while the students write the argument. 


\section{Implications of Findings}

Writing is one of the necessary skills that require Higher Educations' students to master it. By doing so, the students will be obligated to take an academic writing class to learn Page | 81 the procedure to write a good text. The most crucial requirements in writing are both coherence and cohesion as those abilities need prior knowledge from the writer.

\section{Bibliography}

Ahmed, Abdel Hamid. 2010. 'Students' Problems with Cohesion and Coherence in EFL Essay Writing in Egypt: Different Perspectives'. Literacy Information and Computer Education Journal, no. April: 211-21. https://doi.org/10.20533/licej.2040.2589.2010.0030.

Arikunto, Suharsimi. 1999. Prosedur Penelitian: Suatu Pendekatan Praktek. Jakarta: Rineka Cipta.

Ashani Michel Dossoumou, Mahugnon everin mehouenou, Albert Omonlegbe Krokpossi. 2018. 'Appraising the Impacts of Cohesion and Coherence in Benin SS3 EFL Learners' Writing Productions'. International Journal of Linguistics, Literature and Culture 4 (5). Aziz, Imam Nur. 2020. 'The Development of English Grammar Book Through Direct Method: Research and Development Study at Mambaus Sholihin English Course'. Alsuna: Journal of Arabic and English Language 3 (1): 1-18. https://doi.org/10.31538/alsuna.v3i1.643.

Aziz, Imam Nur, and Yuli Ani Setyo Dewi. 2019. 'The Implementation of Contextual Teaching and Learning on English Grammar Competence'. Alsuna: Journal of Arabic and English Language 2 (2): 67-95. https://doi.org/10.31538/alsuna.v2i2.392.

Creswell, John W. 2012. Educational Reserach: Panning, Conducting and Evaluating Quantitative and Qualtative Research.

Crossley, Scott, Danielle Mcnamara, Scott A Crossley, and Danielle S Mcnamara. 2010. 'UC Merced Proceedings of the Annual Meeting of the Cognitive Science Society Title Cohesion, Coherence, and Expert Evaluations of Writing Proficiency Cohesion, Coherence, and Expert Evaluations of Writing Proficiency', no. 32: 32.

Gay, L. R. 2000. Educational Reserach: Competences for Analysis and Apprication. New York: Macmillan Publishing Company. 
Lismay, Leli, and Zubaidah Zubaidah. 2019. 'Strategi Pembelajaran Bahasa Inggris Mahasiswa Mahad IAIN Bukittinggi'. Journal Educative : Journal of Educational Studies 4 (1): 45. https://doi.org/10.30983/educative.v4i1.967.

Mark Briesmaster, Paulo Etchegaray. 2017. 'Coherence and Cohesion in EFL Students' Writing Production: The Impact of a Metacognitve Based Intervention'. Ikala 22 (2).

M.E, Winarno. 2013. Metodologi Penelitian Dalam Pendidikan Jasmani. Malang: UM Press.

N.A.W, Wahyu Dyah. 2016. 'An Analysis of Cohesion and Coherence in the Students' Writing Text'. IAIN Salatiga.

Nicholas, Walliman. 2011. Research Method. New York: Routledge.

Poudel, Ambika Prasad. 2018. 'Academic Writing: Coherence and Cohesion in Paragraph'. In Reserach Gate.

Sholah, Hanif Maulaniam. 2019. 'Enhancing EFL Learners' Writing Skill via Journal Writing'. Alsuna: Journal of Arabic and English Language 2 (2).

Sugiyono. 2016. Metode Penelitian Pendidikan Pebdekatan Kulaitatif, Kuantitatif Dan R\&D. Bandung: Alfabeta.

Suwandi. 2016. 'COHERENCE AND COHESION: AN ANALYSIS OF THE FINAL PROJECT ABSTRACTS OF THE UNDERGRADUATE STUDENTS OF PGRI SEMARANG'. Indonesian Ournal Of Applied Linguistic 5 (2).

Tangkiengsiriin, Supong. 2010. 'Promoting Cohesion in EFL Expository Writing : A Study of Graduate Students in Thailand'. Nternational Journal of Arts and Science. 